\title{
Ev Kadınlarının Tüketimi Algılama Biçimleri: Araban İlçesi Örneği
}

\section{Doç. Dr. Beyzade Nadir Çetin ${ }^{1}$ * Sosyolog Pinar Arslan²}

Geliş tarihi: 24.05 .2019

Kabul tarihi: 20.06.2019

\section{Atıf bilgisi:}

IBAD Sosyal Bilimler Dergisi

Sayl: $5 \quad$ Sayfa: 22-33

Yıl: 2019 Dönem: Güz

This article was checked by iThenticate. Similarity Index 04\%

1 Firat Üniversitesi, Türkiye, beyzadenadircetin@gmail.com, ORCID ID 0000-0002-4560-1331

2 Aile, Calıșma ve Sosyal Hizmetler İl Müdürlüğü Gaziantep, Türkiye, pinar.arslan27@gmail.com,

ORCID ID 0000-0002-7419-8131

* Sorumlu yazar

\section{ÖZ}

Üretilen ürün ve hizmetlerin tüketiciler tarafindan talep edilmesini sağlamak için bir strateji olarak kurgulanan metalaştırma, toplumsal yapıyı oluşturan tüm kesimlerde tüketime ilişkin ortak algı, tutum, tavır ve yaklaşımların oluşturulmasını sağlamaya yönelik olarak işlemektedir. $\mathrm{Bu}$ çalışmada, tüketici kesimlerden biri olan ev kadınlarının tüketime ilişkin geliştirmiş oldukları algı, tutum, eğilim ve yaklaşımların neler olduğu araștırılmıștır. Böyle bir alg1 ortaklaşmasının var olup olmadığının belirlenmesi amaciyla bu çalışma, Gaziantep iline bağlı Araban ilçesinde yaşayan 81 ev kadını ile yapılan derinlemesine görüşmelerden elde edilen nitel verilere dayanmaktadır. Elde edilen verilerden, kapalı bir toplum yapısı içerisinde sosyalleşmiş olmalarına rağmen; ev kadınlarının tüketime ilişkin geliştirilen teorik referans çerçevesine paralel șekilde tüketme eğilim ve pratiklerine sahip oldukları belirlenmiştir.

Anahtar Kelimeler: Tüketim, Tüketim Toplumu, Meta Değeri, Kullanım Değeri, Sembolik Değer. 


\title{
The Perceiving Ways of Consumption of Housewives: The Case of Araban District
}

\author{
Assoc. Prof. Dr. Beyzade Nadir Çetin ${ }^{1} *$ \\ Sociologist Pinar Arslan ${ }^{2}$
}

First received: 24.05 .2019

Accepted: 20.06.2019

\section{Citation:}

IBAD Sosyal Bilimler Dergisi

Issue: 5 Pages: 22-33

Year: 2019 Session: Fall

This article was checked by iThenticate. Similarity Index 04\%

1 Firat University, Turkey, beyzadenadircetin@gmail.com,

ORCID ID 0000-0002-4560-1331

2 Ministry of Family, Labour and Social Services, Gaziantep, Turkey, pinar.arslan27@gmail.com, ORCID ID 0000-0002-7419-8131

* Corresponding Author

\begin{abstract}
The commodification, which is constructed as a strategy to ensure that the produced products and services are demanded by the consumers, works to ensure the creation of common perception, attitudes, manners and approaches regarding consumption in all layers of the social structure. In this study, the perception, attitudes, tendencies and approaches of housewives, who are one of the consumer groups, have been investigated. This study is based on the qualitative data obtained from the detailed interviews with 81 housewives living in the Araban district of Gaziantep province. Although it is seen that they have been socialized in a closed society structure in the light of the data, it is determined that housewives have tendencies and practices towards consumption in parallel with the theoretical frame of references developed for consumption.
\end{abstract}

Keywords: Consumption, Consumer Society, Commodity Value, Use Value, Symbolic Value. 


\section{GİRIŞ}

1970'li yıllardan itibaren tüketim kavramının ele alınışı, kitlelerin tüketim kavramından ne anladıkları üzerine yoğunlaşmaya başlamıştır. Kapitalizmin tüketme kapasitelerini artırma esaslı işlemeye başladığı bu dönemden itibaren toplumdaki bireylerin tüketimden ne anladıkları, tüketmeyi yaşamlarının neresine konumladıkları ve tüketime ilişkin beklenti ve tutumları önem kazanmıştır. Çünkü ortaya çıkan süreçte tüketim, basit şekilde ihtiyaç temelli yapılan bir edim olmaktan çıkarak kültürel temelli gerçekleşen bir faaliyet dizisine ve hayat tarzına dönüşmüştür. Kapitalist olmayan toplumlarda (feodal, tarım ve avc1toplayıc1 gibi) ürün ve hizmetler, kullanılmak üzere üretilen ve kısa zamanda tüketilen metalardır. Ancak sanayileşmenin ideolojik inşacısı olan kapitalizm ile birlikte basit bir ihtiyaç karşılama algısı taşıyan tüketim olgusu, bu niteliğini kaybederek insani faaliyetlerin önemli bir parçası haline gelmiştir (Storey, 2000, s. 136). Kullanım temelli bireysel üretim yerini fabrikalarda gerçekleşen büyük çaplı üretime bırakırken, üretilen ürün ve hizmetlerin kullanıma esas olan anlamlarının ötesinde sembolik anlamları da ortaya çıkmaya başlamıştır.

Böylece tüketim, üretilen ürün ve hizmetlerin faydası temelli tüketildiği biçimindeki algısal temelinden ayrılarak, ürün ve hizmetlerin sahipliği neticesinde kazanılan bireysel statü, prestij, mutluluk ve hazzın kaynağı haline gelen sembolik bir algılama olarak ele alınmaya başlanmıştır. Bu süreçte tüketilen ürün ve hizmetler, ihtiyaç karşılama fonksiyonunun ötesinde bireye kazandırdığı anlamlar bakımından önemli hale gelmiştir. "Tüketim, göstergelerle anlaşılan yeni bir dil oluşturmuştur" (Odabaş1, 1999, s. 16). Tüketim olgusunun algısal boyutundaki bu değişim ise kapitalizm bağlamında ürün ve hizmetlerin üretiminin yanı sıra üretilen ürün ve hizmetlere ilişkin talep yaratma gerekliliğini de beraberinde getirmiş̧ir. Çünkü tüketim temelli toplumsal yapı, ürün ve hizmetlerin satışı için daha kapsamlı ve karmaşık süreçlerin takip edilmesini zorunlu kılmıştır (Zorlu, 2008, s. 54). Sanayileşmenin ilk zamanlarında üretim temelli olarak kurgulanan toplumsal yapı, tüketime ilişkin yeni anlam dünyalarının yaratılması ve tüketim odaklı bir iktisadi sistemin oluşması ile birlikte tüketim temelli olarak kurgulanan bir toplumsal yapıya dönüşmüştür. $\mathrm{Bu}$ dönüşüm ise seri ve hızlı bir biçimde üretilen kitlesel malların satılabilmesine dayalı ve içerisinde yaşayan insanların böyle bir durumu kabullendikleri tüketim toplumu olgusunu ortaya çıkarmıştır. Başından itibaren ürün ve hizmet üretimini artırarak bu ürün ve hizmetlerin tüketilmesini sağlama amacını taşıyan kapitalizm, bu biçimi ile olgu haline gelen tüketim toplumu aşamasında da etkinliğini sürdürmektedir.

Tüketim, tüketim toplumu aşamasında sadece iktisadi bir olgu olmaktan çıkmıştır. Toplumsal yapıyı temelleyen ve yapının ana eksenini oluşturduğu kabul edilen tüketim, bu dönemde toplumsal yapıyı ortaya çıkaran ilişkiler bütününün en önemli unsuru olan kültürün de belirleyicisi olmuştur. Küresel tüketim toplumu olarak adlandırılan yapının kültür örüntüsü ise "tüketim kültürü" olarak belirlenmiştir. Tüketim artık basit bir satın alma ediminin ötesinde kültürel anlamı olan bir olgudur. Hatta tüketim, "kültürün kavgasının verildiği ve biçimlendiği yer" (Douglas ve Isherwood, 1999, s. 73) olarak kabul edilmiştir. Buna göre tüketim toplumunda satışa sunulan tüm ürün ve hizmetlerin ifa ettikleri fonksiyonlarına esas olan kültürel değerleri vardır. Böylece tüketim sadece kullanım amacına yönelik olarak ürün ve hizmetlere harcanan parasal değer olarak değil; tüketilen ürün ve hizmetlerde verili olan sembolik değer yoluyla elde edilen anlam ve hazları da içeren (Fiske, 1999, s. 39) bir değer ölçüsü haline gelmiştir. Dolayısıyla tüketim, günümüz toplumunda üretilen metaların ekonomik değerinin aşıldığı ve satın alınan ürün ve hizmetler yoluyla kazanılan kültürel değerin tartışma alanına dönüşmüştür. $\mathrm{Bu}$ bakımdan tüketime ilişkin olarak toplumsal yapıyı paylaşan bireylerin bakış açıları, algıları, tutumları ve tüketimin önemine ilişkin yaklaşımları da değişmiştir.

$\mathrm{Bu}$ çalışmanın en temel amacı, tüketim toplumu aşamasında yaşayan toplumsal kesimlerden biri olan "ev kadınları"nın tüketim olgusuna ilişkin algı, tutum ve yaklaşımlarının belirlenmesidir. Bu amaçla Gaziantep iline bağlı Araban ilçe merkezinde yaşayan ve herhangi bir işte çalışmayan ev kadınları ile derinlemesine mülakat yöntemiyle görüşmeler yapılmış ve elde edilen veriler analiz edilmiştir. Toplumsal cinsiyet belirlenimleri göz önüne alındığında erkeklerin daha çok üretim, kadınların ise daha çok tüketim merkezli bir yaşayış geliştirdiklerine ilişkin ön kabul, araştırma evreni olarak ev kadınlarının seçilmesinde etkili olmuştur. 
Bir ilçede yaşıyor olmaları dolayısıyla kapalı bir toplum yapısı içerisinde sosyalleşen Araban ilçesindeki ev kadınlarının tüketim olgusuna ilişkin algı, yaklaşım ve tutumlarının ne yönde gerçekleştiğinin belirlenmesi önem taşımaktadır. Zira kentsel alanlarda ya da yaşadığı yerden bağımsız olarak çalışan bir kadın için tüketim toplumu bağlamında tüketimi algılamak ve yaşanan değişim ve dönüşümlere göre yaşam tarzı belirlemek oldukça doğalken, bu tarz bir kapalı toplumda yaşayan ve çalışmayan kadın için tüketim toplumu bağlamında tüketimi algılamak ve yaşanan değişim ve dönüşümler paralelinde yaşam tarzı oluşturmak çok da kolay değildir. Bu bağlamda bu çalışma, tüketmeye ilişkin gerçekleştiği ve yaygınlaştığı düşünülen postmodern tüketme alg1 ve eğilimlerinin gelişmiş kent alanları dışında da belirip belirmediğine iliş̧kin bir soruya yanıt vermeye çalışmaktadır.

$\mathrm{Bu}$ konu ve amaç uyarınca çalışmanın evrenini Araban İlçesinde yaşayan ev kadınları oluşturmaktadır. Bu kapsamda TUiK nüfus verilerine göre Araban ilçesinde, evli, dul ya da boşanmış olma ve aynı anda çalışmama nitelikleri bakımından ev kadını olarak kabul edilen farklı yaş ve eğitim gruplarında 8115 kişinin olduğu belirlenmiştir. Tespit edilen bu evrenden, yaş grupları, eğitim ve medeni durumlarına (boşanmış ya da eşini kaybetmiş olma bağlamında) göre yüzde 10 nispetinde bir örneklem tesadüfi olarak seçilmiştir. Böylece tesadüfi olarak seçilen 81 kişi ile derinlemesine mülakat yöntemi ile yüz yüze görüşmeler yapılmıştır. Gerçekleştirilen görüşmeler sırasında çalışılan alanın kapalı bir toplum yapısına sahip olması dolayısıyla; ses kaydının yapılmasını istememe, eşinden izin alamama ve evde bulunan diğer bireylerden rahatsızlık duyma biçiminde çeşitli güçlüklerle karşılaşılmıştır. Çalışma sırasında bu tür sınırlılıkların giderilmesine ilişkin değerlendirmeler yapılarak oluşturulan örneklem grubuna ekleme ve çıkarmalar yapılmak zorunda kalınmıştır. Bu sınırlılıklar ile çalışma tamamlanmış ve Yüksek Lisans tezi olarak sunulmuştur.

\section{Ev Kadınlarının Tüketimi Tanımlama Biçimleri}

Fromm (2018)'a göre, endüstriyel aşama ile birlikte tasarruf etme biçiminde birikimin erdem olarak kabul edildiği anlayış yerini tüketebilmenin bir meziyet olarak sayıldığı algılamaya bırakmıştır. Yaşamın anlamı değişerek, ürün ve hizmetin sahibi olmanın özgürlük ve mutluluğun kaynağına dönüştüğü bir zaman yaşanmaya başlamıştır. Homo Faber (üreten insan) yerini Homo Consumens (tüketen insan)'e bırakmıştır. Tüketime ilişkin algılamada gerçekleşen bu değişim, zaman içerisinde tüketmenin ihtiyaç için gerçekleştiği anlayışı ile tüketimin daha çok tüketilen metada gizli olan sembolik anlam için gerçekleştiği biçimindeki anlayış şeklinde ikili bir tanımlamaya sebep olmuştur. Tüketime ilişkin algı, tutum ve yaklaşımlar belirlenirken ya ihtiyaç temelli ya da sembolik anlam temelli olarak elde edilen haz ve mutluluk şeklinde tanımlamalarla karşılaşılmaktadır.

Tüketim, kelime anlamı olarak daha çok bitirmek, ziyan etmek, sarf etmek, ortadan kaldırmak ve yok etmek biçiminde tanımlanırken, bu tür tanımlamalar günümüz tüketim toplumu başta olmak üzere tarihsel süreç içerisinde tüketime ilişkin yaklaşım ve algılamaları belirlemekte yetersiz kalmaktadır. Benzer biçimde bu yetersizlik beraberinde tüketime ilişkin olumsuz bir algılayışı da getirmektedir. Ancak tüketim olgusu kelime anlamından bağımsız olarak en temelde "herhangi bir ürün ya da hizmetin seçilmesi, satın alınması, kullanılması, onarılması ve atılması" (Üstün ve Tutal, 2008, s. 3) şeklinde tanımlanabilir.

Tüketim olgusunun tam bir tanımına ulaşmak yerine tüketime ilişkin geliştirilen algı ve yaklaşımların belirlenmesi, kavramın anlaşılması açısından daha ufuk açıcıdır. $\mathrm{Bu}$ bağlamda bu çalışmada katılımcılardan, tüketmeye ilişkin algı, tutum, yaklaşım ve eğilimlerini belirlemek için tüketime ilişkin hislerini anlatmaları istenmiştir. Örneklem grubunun kavramsal olarak aynı algıya sahip olması için tüketim kavramı yerine yapılan görüşmeler sırasında alışveriş kavramı kullanılmıştır. Alınan yanıtlar değerlendirildiğinde ise katılımcıların, tüketime ilişkin akademik tanımlamalara benzer biçimde, tüketimi hem ihtiyaç temelli hem de mutluluk ve haz sağlayan sembolik temelli olarak değerlendirdikleri saptanmıştır.

\section{Tüketime Yönelik İhtiyaç Temelli Tanımlamalar}

Araştırma kapsamına giren ev kadınlarının zihinlerinde yerleşmiş olan tüketim kavramının ne anlama geldiğini öğrenmek adına "Sizce Alışveriş nedir? Alışveriş deyince aklınıza ne geliyor?" şeklinde sorular yöneltilmiştir. Bu soruya verilen yanıtlar değerlendirildiğinde deneklerin bir kısmının tüketimi "ihtiyaç temini” biçiminde tanımladığı anlaşılmaktadır. Özellikle araştırma kapsamına giren ev kadınlarından 
F.Ö. (67)'nün "alışveriş, evinin zaruri ihtiyaçlarını almaktır", Z.Ö. (55)'nün "alışveriş evin zaruri ihtiyaçlarını, normal ihtiyaçlarını almaktır", H.A. (55)'nın "alışveriş deyince aklıma tüm ihtiyaçlar geliyor" ve G.P. (78)'nin "alışveriş deyince ne gelecek aklıma, evinin ihtiyaçlarını görmek gelir" şeklindeki ifadeleri, ihtiyaç temelli tüketim tanımlamalarının genel sınırını çizmektedir. İhtiyaç temelli tüketim tanımlaması yapan ev kadınlarının en temel niteliği 50 yaşın üzerinde olmaları ve ihtiyaç kavramını, ev ve zaruri ihtiyaçlar biçiminde en temel ihtiyaçlara indirgemiş olmalarıdır. Bu tanımlamalarda yer alan zaruri ihtiyaç ise daha çok yeme içme gibi fizyolojik ihtiyaçlar ile ev için birincil derecede önemli olan mutfak eşyalarıdır. Zaruri ihtiyaç ya da ihtiyaç tanımlamaları ise S.O. (54) ve H.A. (55)'nın "zaruri ihtiyaçlar, mutfak eşyasıdır", A.K. (61)'nin "nasıl diyeyim, aklıma mutfak malzemesi gelir", Ü.B. (70)'nin “alışveriş deyince yiyecek içecek ne bileyim” ve F.Ç. (34)'nin "alı̧̧veriş deyince aklıma mutfak gelir. Çoğunlukla mutfak, sebzeymiş, yiyecek-içecek, un bulgur, şeker, ondan sonra sebze-meyve gelir" biçimindeki yanıtlarından belirlenmektedir. Özellikle 50 yaş üzeri katılımcıların neredeyse tamamı tüketimi, zaruri ihtiyaçların giderilmesi olarak tanımlamış ve bahsi geçen zaruri ihtiyaçların ise mutfağa ait ve basit yaşama ilişkin fiziksel ihtiyaçların teminine yarayan ürünlerle sınırlı olduğunu belirtmişlerdir. Dikkat edilirse burada ifade edilen ihtiyaçların tamamı, ürün ve hizmetlerin kullanım değeri temelli olarak idrak edilmesi ile belirlenmiştir. Yine aynı soruya verilen yanıtlardan zaruri ihtiyaç olarak tanımlanan bir diğer ürün ve hizmetin ise ev yaşamına ilişkin eşyalar olduğu, H.A. (55) ve A.K. (61)'in "ev eşyasıdır" ş̧eklinde verdikleri yanıtlardan anlaşılmaktadır. Görüşmecilerin vermiş oldukları yanıtlar genel anlamda değerlendirildiğinde; ihtiyaç temelli tüketim algısı ve eğiliminin, normal ihtiyaç biçimindeki bir kavramlaştırma ile ortaya konulduğu anlaşılmaktadır. Yaşamın basit döngüsü içerisinde sadece hayatı sürdürme esaslı olarak sınırlanan normal ihtiyaç kavramı, tüm ihtiyaçlar olarak tamamen evin fiziksel olarak var olmasına dayalı ürün ve hizmetleri kapsamaktadır. Fakat burada dikkat edilmesi gereken husus, tüketime ilişkin böyle bir değerlendirmenin sadece 50 yaş üzeri katılımcılar tarafindan yapılıyor oluşudur.

Tüketimi ihtiyaç temelli olarak tanımlayan ev kadınları arasında ihtiyacın biçimlenişine göre farklılıklar ortaya çıkmaktadır. Bu farklılığın temelinde ise yaş faktörü yer almaktadır. Buna göre 50 yaş üzeri kadınların büyük çoğunluğu ihtiyacı ev ve mutfak eşyası biçiminde zaruri ihtiyaçlar olarak tanımlarken; 50 yaşın altında olan kadınların büyük bir çoğunluğu ihtiyacı, kendi bedenlerine ya da dış görünümlerine ilişkin yaptıkları harcamalar olarak tanımlamışlardır. Buna göre araştırma kapsamına giren ev kadınlarından Z.G. (25)'nin "klyafet almaktır, ondan sonra ayakkabı almaktır", G.G. (48)'nin "ihtiyaç, kllık klyafet türü şeylerdir iş̧e”, F.A. (27)'nın "alı̧̧veriş deyince aklıma klyafet gibi şeyler gelir", B.K. (36)'nın "ben klyafeti çok sevdiğim için klyafet gelir", H.O. (24)'nun "alışveriş deyince kendime, klyafete çok önem veririm”, D.Ş (26)'nin "alışveriş ihtiyaçlarımı gidermektir. Bir şeyler almaktır. Alı̧̧veriş deyince benim aklıma klyafet gelir. Ayakkabl, çanta gelir mesela" ve G.Ö. (31)'nün "alışveriş derken giyim çocuk giyimi ve sonra eşyaları ve ondan sonra güzel giyinmek aklıma gelir" şeklindeki cevapları, bu tanımlamayı desteklemektedir. Özellikle genç yaş grubunda olan deneklerin büyük kısmı, tüketimi; kendilerine veya yakınlarının bedenlerine (anne, baba, kardeş, eş veya çocuklarının giyim vb. ihtiyaçlarını içeren giyim ve kuşam ürünleri) yaptıkları harcamalar biçiminde tanımlamaktadırlar. "Zaruri ihtiyaç" kavramı 50 yaşın altındaki ev kadınlarında daha çok "ihtiyaç" (sadece yaşamsal döngünün devamına yönelik ürünler) olarak kodlanmış ve ihtiyaçlar hiyerarşisinde fiziksel ihtiyaçlardan çok sonra gelen ihtiyaçları belirlemek için kullanılmıştır. Bu noktada, 50 yaşın altındaki ev kadınlarının tüketimi ihtiyaç temelli olarak tanımlamalarına rağmen; tüketimin kullanım değerini aşan ve sembolik anlamlar üzerinde temellendiği tüketim toplumu yapısının kendilerinden beklediği biçimde sosyalleşmiş oldukları söylenebilir. Bu durumda yaş faktörü, tüketime ilişkin algılama ve tanımlamalarda sembolik değer temelli tüketim edimi ile kullanım değeri temelli tüketim edimi arasındaki farkın açıklanması bakımından önemli bir referans noktasıdır.

İhtiyaç temelli algılamalar içerisinde sınıflanabilecek olan bir diğer tanımlama F.Ö (43)'nün "alışveriş para harcamaktır" ve A.K. (19)'nin "alışveriş deyince direkt para aklıma geliyor" ş̧eklindeki yanıtlarında yansımasını bulan ve ihtiyaç kavramının para harcanan her türlü ürün ve deneyime referans tutulduğu algılamadır. Bu algılama ise herhangi bir alım-satımın konusu olan ürün ve deneyimin meta olduğu şeklindeki teorik kabule destek niteliğindedir. İhtiyaç karşılama biçiminde değerlendirilen tüketimin, kullanım değeri esaslı işlediği kabul edildiğinde; bu kullanım değerinin karşıllğı olan bir mübadele değerinin de belirlenmesi gerekmektedir. Araştırma kapsamına giren katılımcılar, metanın 
kullanım değerine karşılık olarak belirlenmiş olan mübadele değerini, metaya yüklenmiş bir anlam olarak algılamaktadır. Bu algılamanın temeline inebilmek adına araştırma kapsamına giren ev kadınlarına "Aldığınız/alacağınız bir ürünün neyi önemlidir?" șeklinde soru yöneltilmiştir. Bu soruya verilen yanıtlardan, tüketime ilişkin ihtiyaç temelli tanımlama yapanların büyük bir kısmının aldıkları ürün ya da hizmetin ucuz olmasını bekledikleri anlaşılmıştır. Bu soruya verilen yanıtlardan bir diğeri ise ihtiyaç temelli tüketim tanımlaması yapanların bir kısmının ihtiyaç gidermek amacıyla alınan ürünün kaliteli olmasını önemsediklerini ortaya koymuştur. Buna göre B.P. (36) "fiyatı önemlidir", N.Ö. (39) "ucuzluk önemlidir", D.Ş. (26) "kesinlikle ucuzluk önemlidir", Y.Ö. (44) "benim için şimdilik ucuzluk", İ.Ç. (26) "aldiğım ürünün fiyatı önemlidir", F.K. (35) "fiyatı çok önemlidir", H.K. (44) "uygunluğu, ucuzluğu önemlidir", A.Y. (47) "ucuzluğu önemli benim için" şeklindeki yanıtlar, ihtiyaç temelli bir tüketim edimi sırasında fiyatın oldukça önemli olduğunu belirtmektedir. Yine E.Ç. (63) "kalitesi çok önemli, kötü bir şey hiç almam", D.D. (70) "kaliteli olması önemli", H.E. (62) "kaliteli olması iyi valla", H.G. (57) "kalitesi çok önemli. Kalite olmazsa elime almam", A.K. (64) "kalitesi önemli, kaliteli bir şey olmazsa almam hiç" ve Ü.B. (70) "iyisi önemli kalitesi yani" şeklindeki yanıtlar ise ihtiyaç karşılama için de olsa alınacak ürünün kaliteli olmasını beklediklerini göstermektedir. Dikkat edilmesi gereken husus, verilen yanıtların yaş dağılımlarına bakıldığında 50 yaş ve üzeri olan ev kadınlarının alınacak ürünlerin kalitesine önem verdikleri, 50 yaşın altındakilerin ise ucuzluğuna önem verdikleridir. Verilen yanıtlardaki yaş faktörüne göre ortaya çıkan farklılaşmanın, ihtiyacı tanımlama konusundaki farklılaşmaya benzediği söylenebilir. İhtiyaçları zaruri ihtiyaçlar olarak tanımlayan 50 yaş üzeri ev kadınları, ev eşyası ve mutfak harcamaları olarak tanımladıkları ihtiyaçlar için kaliteli olma niteliğini ön planda tutmaktadır. İhtiyacı, kendi bedenlerine harcama yapmak ve görünümü iyileştirmek üzerinden tanımlayan 50 yaş altı ev kadınları ise, ihtiyaçları için ucuz olması yönüyle fiyat niteliğini ön planda tutmaktadır. Bu nitelik farkının, görünümü esas alan giyim-kuşam gibi ihtiyaçların çeşitlilik ve nicelik yönünden fazla olması gerekliliği ile zaruri ihtiyaç olarak tanımlanan mutfak ve ev eşyalarının belirli, kısmi ve nitelik yönünden değerlendirilmesi gerekliliğinden kaynaklandığı söylenebilir. Örneğin eve alınacak bir yiyeceğin ya da ev eşyası olarak bir halının, fiziksel ihtiyacı gidermesi ve sağlık yönünden değerlendirilmesi gerektiğinden kaliteli olması gerekirken; kişinin görünümünü ilgilendiren giysilerin çeşitli ve bolca olması gerektiğinden ucuz olması esastır. Çünkü bir kadının birden fazla ve çeşitli zaman ve yerlerde kullanılmak üzere giysilerinin olması beklenmektedir.

Tüketimi ihtiyaç temelli tanımlama bakımından Araban'lı ev kadınlarının yaş değişkenine bağlı olarak farklılaştıkları belirlenmiştir. 50 yaş ve üzeri ev kadınlarının neredeyse tamamı tüketimi, zaruri ihtiyaçların temini biçiminde tanımlarken, 50 yaşın altındaki ev kadınlarının bir kısmı ihtiyaçların giderilmesi, bir kısmı ise ihtiyaç giderimi için para harcamak şeklinde tanımlamışlardır. Bu tanımlamalara göre, her ne kadar ihtiyaç temelli tanımlamış olsalar da 50 yaş altı ev kadınlarının kullanım değeri bağlamında değil sembolik değer bağlamında tüketim edimi gerçekleştirdikleri söylenebilir. Çünkü zaruri ihtiyaçların karşılanması biçimindeki tanımlama, fiziksel ihtiyaçların giderilmesi ve kullanıma esas faydalı ürünlerin satın alınması biçimindeki bir tüketim eğilimine işaret ederken; giyim-kuşam şeklinde genellenebilecek olan beden ve dış görünüşe yönelik gerçekleşen tüketim edimi, tüketilen ürün ve deneyimlerde yüklü olan prestij ve statü anlamına dayalı aidiyet ve gösteriş değeri uyarınca gerçekleşmektedir. Bu yönüyle 50 yaş altındaki ev kadınlarının özellikle sosyalleştikleri zaman dilimi göz önüne alındığında, tüketim toplumu yapısı içerisindeki yaşam tarzına daha yakın tüketim algılayışına sahip oldukları söylenebilir. Tüketimi ihtiyaç temelli tanımlamış olmalarına rağmen; 50 yaş altındaki ev kadınlarında tüketime ilişkin gizil de olsa bir sembolik temelli tanımlama durumu söz konusudur.

\section{Tüketime Yönelik Sembolik Temelli Tanımlamalar}

Günümüzde birey, ürün ve hizmetleri bir meta olarak satın alan kişi değil aynı zamanda tükettiği ürün ve hizmetlerle kendisini bir meta olarak sunan kişidir. Çünkü tüketilen metalar, tüketen birey ve toplumdaki diğer bireyler için yeni bir prestij algısı yaratmaktadır. Böylece tüketilecek ürün ve hizmetlerin değerleri, tüketicilerin zihninde canlandırdıkları anlam temelinde belirlenmekte, bu anlamlandırma ise değerler sisteminde biçimlenmektedir (Wernick, 1996, s. 67). Bir ürün ve hizmeti satın alan tüketici, toplumsal yapıda bu ürün ve hizmetin içerdiği anlam üzerinden değer bulduğunu düşünmekte ve metaları bu şekilde değerlendirmektedir. Metaların bireyler tarafından bu şekilde değerlendirilmesi ise tüketim kültürünün araçları tarafindan bireylerin manipüle edilmesi ile gerçekleşmektedir. 
Tüketme edimi sadece iktisadi bir karar verme süreci değildir. İçerisinde psikolojik, kültürel ve toplumsal değerlendirmelerin de olduğu bir süreçtir. Bu bakımdan tüketim sadece ihtiyaç giderimi ile ilgili olmayan, aynı zamanda arzu, haz ve isteklere de dayanan bir olgudur. Özellikle tüketim toplumunda birey, tüketimi ekonomik anlamda kullanım amaçlı ve faydaya dayanan bir faaliyet olarak görmemekte; tüketilen ürün ve hizmetin içerisinde taşıdığı gösterge, sembol, imaj ve işaretlerin bulunduğu toplumsal ve kültürel bir olgu olarak algılamaktadır (Bocock, 2009, s. 10-14). "Tüketim toplumunda metaların işlevsel olmaları yanında kültürel değerleri vardır". Bu sebeple metaları sadece maddi olarak değil, anlam ve hazzın söz konusu olduğu sembolik değerleri üzerinden de değerlendirme eğilimi söz konusudur. $\mathrm{Bu}$ nedenle günümüzde metalar, bu eğilimden olarak farklı biçimlerde ve anlamsal olarak geniş bir perspektifte ele alınmalıdır. Metalaştırma olarak adlandırılan bir süreçte ve çeşitli metalaştırma araçları (moda, medya, reklam, marka, şirket gibi) dolayımıyla anlam olarak yeniden üretilen metalar (Çetin, 2017), tüketilen ürün ve hizmetler olmalarının yanı sıra anlam, haz, istek ve arzunun üreticisi durumuna gelmektedir (Storey, 2000:, s. 138). Baudrillard, buzdolabı örneği üzerinden konuyu örneklemektedir. Buna göre buzdolab1, bir mutfak eşyası olarak fayda esaslı bir ihtiyaç gidericiyken; konfor, prestij, rahatlık gibi gösterge ve sembolleri taşıması yönüyle sembollerin tüketilmesidir (Baudrillard, 2012: 18). Ona göre tüketim, artık gösterge ve sembollerin satın alınmasıdır. Çünkü tüketim nesneleri birer göstergeye dönüşmüştür. Featherstone için de tüketim, gösterge ve imajların değişimidir. Basit bir hediyeleşme durumunda bile hediye verilen nesnenin iletmek istediği bir mesaj vardır (Featherstone, 2013, s. 44). Tüm bunlardan olarak tüketim, basit bir ihtiyaç giderimi değil tüketilen ürün ve hizmetlerin tüketen bireylere simgesel olarak konum, prestij, haz ve mutluluk kazandırdığ 1 bir faaliyettir. Tüketim toplumunda metalar sembolik olarak da tüketilmektedir. Artık tüketim nesneleri basit nesneler değildir. Onlar, bünyelerinde çeşitli anlamların gizli olduğu anlam taşıyıcılarıdır. Bu sebeple tüketim olgusu artık basit bir nesne değiş-tokuşu olarak değil; kodlarla ve imajlarla işleyen bir gösterge sistemi olarak ele alınmalıdır (Baudrillard, 2012, s. 26-19).

Tüketim metaları, bireylerin kimlik kazanmalarını sağlayan sembolik anlamlarla doludur (Bocock, 2009, s. 59). Bu nedenle tüketim Baudrillard tarafindan adeta var olma modu olarak değerlendirilmiștir (Şaylan, 2009, s. 300). Tüketilen ürün ve hizmetler "bireylerin kim olduklarını gösterme duygularını (mutlu/mutsuz gibi) ortaya koyma ve çevrelerindeki diğer bireylerle iletişim kurmaları" yönüyle (Odabaşı, 1999, s. 8) işlev görmektedir. Böylece alınan ürün ve edinilen deneyimler, sıradan bir satın alma edimi olarak kalmamakta, satın alınmaları ile alıcının kim olduğunu (Yanıklar, 2006, s. 117) ve ne hissettiğini de ortaya koymaktadır.

Tüketimi bu yönüyle analiz eden bir diğer teorisyen Veblen'dir. Ona göre tüketimi bir tür var oluş ve kendini gösterme biçimi olarak kullanan bir sınıf yapısı ortaya çıkmıştır. Aylak sınıf, üretimci olmadığını ve lüks tüketim metalarını tüketebildiğini göstermeyi yaşam tarzı haline getirmiş olan toplumsal bir tabakadır. Aylak sınıf açısından tüketilen ürün ve hizmetler farklılığın göstergeleridir (Veblen, 2005, s. 61). Gösteriş tüketimi olarak adlandırılan bu tür tüketim edimi, tüketilen metalar yoluyla kimlik ve prestij kazanılacağına olan inancın en temel göstergesidir. Artık birey tükettiği metaya göre anlam kazandığını düşünmekte ve saygınlık gördüğüne inanmaktadır. Tüketilen metanın nevi, tüketen bireyi mutlu ya da mutsuz etmekte, tükettiği şeyler temelinde statü kazandığına inandırmaktadır.

Gösterişçi tüketimin en net şekilde göründüğü alan giyim-kuşamdır. Giysi, bireyin ne tür mallar tüketebildiğini gösterdiği en temel göstergedir. Bu bağlamda giyim-kuşam temelli gösteriş tüketimi algısının en fazla geliştiği toplumsal cinsiyet kadınlardır. Kadın, her şeyden önce üretim alanı dışında ve ev içinde adeta evin süsüdür. Kadın çalışmıyor olsa bile bağımlı olduğu kişinin tüketim yapabilme kapasitesini göstermektedir. Bu yönüyle bağımlı olduğu kişiyi yansıtmaktadır (Erkilet, 2012, s. 32). Tüketim nesnelerinin gösteriş yolu ile kişiyi yansıtması, bu metaların gizli işlevlere sahip olmasından kaynaklanmaktadır. Bu nesnelerin statü ve his gösterimini sağlayan gizli işlevleri vardır (Coser, 2008, s. 244). Örneğin yemek yemek, tek başına başka bir tüketim anlamına sahipken; mum 1şığında ve pahalı bir mekânda gerçekleşmesi ile bambaşka bir anlama sahiptir. Birey açık açık ben zenginim diyemez ama tükettikleri ile bunu gösterebilir ya da birey mutlu ya da mutsuz olduğunu açıklayamaz ama tükettikleri ile bu hislerini gösterebilir. Çünkü tüketim artık sembollerin tüketilmesidir. Bu bakımdan tüketimin sembolik anlamları, tüketim analiz ve tanımlamalarına daha çok haz almak, mutlu olmak, zevkli bir uğraş olmak ya da kişiyi iyi hissettirmek olarak yansımaktadır. 
Araştırma kapsamına giren ev kadınlarında da teorik olarak analizi yapıldığı biçimde sembolik tüketim algılayışları ortaya çıkmıştır. Tüketim, ev kadınları için zevkli bir uğraş, mutluluk verici bir faaliyet ve güzel olan bir edim olarak tanımlanmıştır. Araban ilçesi bağlamında kapalı toplum yapısı özelliği gösteren bir yerde bile ev kadını olmak tüketim kültürünün özümsenmesini engelleyememiştir. $\mathrm{Bu}$ bağlamda araştırma kapsamına giren ev kadınlarının büyük çoğunluğu tüketimi sembolik anlamları üzerinden "zevkli, mutluluk verici, huzur sağlayıcı" bir etkinlik olarak tanımlamışlardır. "Sizce Alışverişs nedir? Allşveriş deyince aklınıza ne geliyor?" şeklinde sorulan araştırma sorusuna P.P (25) "Alışveriş benim için bir zevktir. Güzel, hoş bir şey yani", A.K. (19) "Alışveriş benim için dünyanın en güzel şeyidir. Ondan sonra aklima mutluluk geliyor.", N.Ö. (43) "Allşveriş deyince zevk aklıma gelir." ve Z.G. (25) "Mutlu olmak gelir aklıma" biçiminde yanıtlar vermiştir. Verilen yanıtlardan tüketimin kadınlar tarafindan zevkli bir uğraş ve hoşa giden bir duygu olarak anlaşıldığı görülmektedir. Özellikle genç yaşta olan katılımcıların, tüketimi sembolik olarak değerlendirdikleri ve ihtiyaç karşılamanın ötesinde anlamlarla tanımladıkları söylenebilir. 19-30 yaş aralığında olan ve yeni evli olanların, çocuk bakımı ile alakalı sorumluluk taşımamalarına bağlı olarak böyle bir eğilimi taşıdıkları ve tüketmeye dair bu tarz bir tanımlama geliştirdikleri dikkatlerden kaçmamaktadır. Tüketime ilişkin bu tarz yaklaşım ve tanımlamalar ise "tüketici bireyin aradığı gerçekliğin, zevk arayışının kendisinde" (Robins, 1999, s. 179) gizli olduğu duruma işaret etmektedir. Tüketmenin zevk ve haz ile eşleştirilmesine ilişkin teorik kabul, zevk arayışı kavramlaştırması temelinde araştırma kapsamına giren genç yaştaki ev kadınları tarafından da belirtilmiştir. Buradan olarak ev kadınları sembolik temelli olarak arayışı tüketme eğilimindedir.

Bauman'a göre tüketim, zevkli duyumların yaşandığı ve parlak deneyim fırsatlarının gösterişli ürünlerin tercihi ile ortaya çıktığı tüketici yaşamıdır. Tüketim toplumunda yoksun olmak, tüketerek mutlu ve zevkli bir yaşamı elde edebilme imkanının yokluğuna işaret etmektedir. Böyle bir durumda ise tüketemeyen birey kendini değersiz görmekte ve mutsuz olmaktadır. Tüketim toplumunda normal olarak algılanan yaşam, zevkli duyumlar ve görkemli gösterilere katılım ile ortaya çıkan tüketici yaşamıdır (Bauman, 1999: 60). Bu toplumda tüketemeyenler kusurlu tüketiciler olarak kategorize edilmekte ve tüketemeyenler, tüketememenin bir kusur olduğunu kabul etmektedir. Böylece tüketim toplumunda mutlu olmak, mutlu bir yaşam sürmek; mutlu bir yaşam sürmek ise tüketebilmekle eşitlenmiştir.

Araştırma kapsamına giren ev kadınlarının verdikleri yanıtlardan, Bauman'ın işaret ettiği anlamda bir anlayış ve algılayışın Araban'daki ev kadınları arasında da yaygın şekilde var olduğu ortaya çıkmıştır. Buna göre, "Alışveriş yaptı̆̆ınızda ne hissedersiniz?" şeklinde sorulan soruya katılımcilardan R.A. (20) "Mutluluk duyarım. Güzel bir mutluluk duygusu. Dünyanın en güzel kadını ben zannederim. Çünkü o an öyle oluyor. Çok güzel bir duygu, Çok neşeli oluyorum.", A.K. (19) "Kendimi böyle dünyanın en mutlu insanı hissederim. Çünkü o kadar ki, giyinmekmiş, harcamakmış benim işimdir. O yüzden mutlu oluyorum.”, D.Ö. (34) “Mutlu olurum.”, G.Ö. (31) “Kendimi çok mutlu hissederim. Çok mutlu oluyorum. Para harcamayl çok seviyorum. Böyle alınca hani giyince değişik şeyler üzerimde hani görünce farklı hissediyorum, motive oluyorum açıkçası. Hani alışveriş yaparken motive oluyorum. Deşarj oluyorum açıkçası.", Ş.Y. (30) "Dünyanın en güzel şeyi. Mutluluk duyuyorum. Hoşuma gidiyor, Stres atıyorum. Çok güzel yani.", N.Ö. (35) "Mutlu olurum hani kendim için bir şey alırım. Ya mutlu olurum kendim için bir şey yapıyor olurum, hiç yoktan kendi kendime özen gösteririm hani." ve P.K. (35) "Sevinirim. Mutlu olurum, hoşuma gider." şeklinde yanıtlar vermişlerdir. Verilen yanıtlara göre, ev kadınları için tüketim, mutluluktur. Tüketim sürecinden mutluluk duymaktadırlar. Tükettikçe mutlu olan kadın, kendini özel hissetmektedir. Araştırma kapsamına giren ev kadınları özellikle giyim gibi kendi bedenlerine yaptıkları harcamalardan daha çok mutluluk duymaktadır. Kendilerine ve kendi bedenlerine özen göstermek adına yapılan tüketimin ev kadınları için daha önemli olduğu yapılan görüşmelerden saptanmıştır. Ev işleri ve ev yaşamı dışında hiçbir sosyal faaliyeti olmayan ev kadını için tüketim ayrıca evin iş yükü ve stresini attığ 1 bir faaliyet olarak görülmektedir. Yine dikkat edilirse, tüketim uğraşını mutluluk olarak algılayan ev kadınları genç yaştakilerdir. Tükettikçe kendini mutlu ve özel hisseden ev kadınları, aynı zamanda tüketimin motive edici bir uğraş olduğunu ifade etmektedir. Bu bağlamda genç yaştaki ev kadınları için tüketim, haz duygusunu beraberinde getirmektedir. Kadınlar, yaptıkları harcamalarla mutlu olurken aynı zamanda kendilerini değerli ve özel hissetmektedir.

Tüketim toplumunda ideal olan, ürün ve hizmetlerin tüketiciler tarafından tam olarak benimsenmesi ve tüketim neticesinde arzu ve isteklerin sonlanması değildir. Sınırsız sayıda ürün ve hizmet sunumu olduğundan dolayı tüketiciler her zaman geçici heves ve arzuları/isteklerin sahibi olmalıdır. Geçicilik 
esas olan algılayıştır. Tüketim ile elde edilen sembolik anlamlar geçici ve uçucu olmalı ve gerçekleşen tüketimin yeni heves ve arzulara sebep olacak şekilde düzenlenmesi gerekmektedir (Bauman, 1999, s. 42). Tüketim toplumunda önemli olan, arzuların hiçbir zaman tam olarak doyurulmamasıdır. Bu sebeple tüketilen ürün ve hizmetlerin yeni anlam ve değerlerle yeniden tüketicilere dayatılması gerekmektedir. Tüketim gerçekleşirken elde edilen haz duygusu, geçicilik üzerine inşa edildiğinden dolayı tüketime ilişkin duyulan mutluluk ve zevk de geçicidir. Tüketim toplumunda kalıcılıktan uzak bir tatmin duygusu yaşanmaktadır. Baudrillard'a göre, hazza yönelik olarak gerçekleşen tüketim davranışları esasında başka amaçlarla gerçekleşmektedir. Önemli olan tüketilen ürün ve hizmetlerin bireylere fayda temelindeki hizmeti değil; göstergeler üzerinden gerçekleşen toplumsal bir değiş-tokuşun sağlanmasıdır. Bu sebeple bir tüketim tanımı yapılacaksa geçici heves ve mutluluklara dayalı bir edim olarak ele alınmalıdır (Baudrillard, 2016: 83-84). Haz duygusundan ziyade geçici mutlulukların temeli olan tüketim, tüketim toplumunda sürekli yinelenen yeni heves ve mutluluk arayışlarının cevabı olarak algılanmaktadır.

Bu bağlamda "Alışveriş yaptığınızda ne hissedersiniz?" şeklinde sorulan soruya, araştırma kapsamına giren ev kadınlarından İ.Ç. (26) "Alışveriş tabi zevk veriyor. Yeni bir şeyler almanın verdiği bir zevki oluyor kadının. Allşveriş yaparken aslında bazen sıkılıyorum. Aslında çoğu zaman sıkllyyorum da. Tabi kıyafet alınca zevk aldığımız noktalar da var." şeklinde yanıt vermiştir. Buna göre tüketim her ne kadar zevk veren bir süreç olsa da yaşanan hazzın sonlu olduğu ve daha tüketim süreci sırasında bile bu hazzın sona erdiği belirlenmiştir. Tüketim, bu bağlamda sıkılganlık duygusunu da beraberinde getirmektedir. Alınan zevk ise özellikle bedene yönelik yapılan tüketim esnasında sıkılganlıktan hazza doğru sürekli bir değişime sebep olmaktadır. Yine sorulan soruya görüşmecilerden H.U. (41)'nun “Mutlu olurum. Çok güzel oluyor da çok yorucu, ben çok yorgun olduğum zaman çok fazla almıyorum. Bir de seçenek çok fazla ve kaliteli ürün yok piyasada, çok beğenmiyorum, yorgunlukla birlikte usanmışlık, bıkkınlık da var. Böyle bir an evvel bitsin de eve gidelim moduna giriyor artık. Bir hevesle gidiyorsun, aradığın şeyi çok zor buluyorsun hani zor bulduğun için de yoruluyorsun." şeklinde verdiği yanıttan; tüketimin belli bir süreçte bıkkınlık ve yorgunluk anlamı vardır. Tüketirken ortaya çıkan bıkkınlık ve usanmışlık duygusunun ilk sebebi hazzın hızlı bir șekilde sonlanması iken; aranan ürün ve hizmetin hızlı bir șekilde elde edilememesi de bir başka sebebidir. Görüşmecinin bu tarz bir değerlendirmede bulunmasının sebebi ise yaşadığı ilçe olan Araban'ın tüketim yapabilme bakımından çeşitli yetersizliklere sahip olması olabilir. Dolayısıyla aradığını bulamamak tüketimden alınan haz duygusunun yaşanmasına engel olmaktadır. Tüketim sürecinden kaynaklanan sıkılganlık ve usanmışlık duygusunun bir diğer sebebi de tüketimden alınan zevk ve mutluluk duygusunun kısa süreli olmasıdır. Araştırma kapsamına giren ev kadınlarından B.P. (36)'nin “Çok mutlu olurum. Mutlu olurum tabi istediğim şeyi alırsam. Mutluluğum çabuk geçer sonra, elde ettikten sonra pek bir değeri kalmıyor bazı şeylerin." şeklindeki yanıtı bu sebebi ortaya koymaktadır. Tüketimden alınan haz duygusu kalıcı değildir. Geçicilik üzerine işleyen bir süreç söz konusudur ve bu minvalde sosyalleşen her tüketici, Bauman'ın işaret ettiği tarzda bir tüketim eğilimi ve yaklaşımı sergilemektedir.

Tüketimi sembolik anlamı üzerinden tanımlayan ev kadınları, tüketimi zevk ve mutluluk verici bir süreç olarak tanımladıkları gibi özgürlük, çılgınlık, hastalık ve yaşamın merkezi unsuru şeklinde de tanımlamışlardır. Tüketim, hem ihtiyaç tatmini bağlamında rahatlatan ve yaşamın devamına ilişkin bir süreç olarak algılanırken hem de sembolik bakımdan tüketebilmenin ortaya çıkardığı özgür olma hali ile de algılanmaktadır. Çünkü tüketim alanı tüketim toplumunda sınırsız ürün ve hizmet arzı ile satın alma hususundaki sınırsız özgürlüğü sembolize etmektedir. Yapılan görüşmelerde ev kadınlarından F.Ç. (34)'nin “Kendimi rahat ve özgür hissederim." ve D.Ş. (26)'nin “Alışveriş yaptı̆̆ımda daha özgür olurum." biçimindeki yanıtlarından da anlaşılacağı üzere tüketebilmek, tüketim toplumunda alışveriş sürecine katılabilmek, ürün ve hizmetlerin sembolik anlamlarını tüketebilmekten geri kalmamak anlamında tüketiciyi özgür hissettirmektedir.

Araştırma kapsamına giren ev kadınlarının tüketimi tanımladıkları bir başka algılayışları ise tüketimin bir çılgınlığa karşılık geldiğine ilişkindir. Tükettikçe kendini özgür hisseden ev kadını, sınırsız bir evrende sınırsız ürün ve hizmet almaya muktedir olmayı çılgınlık boyutunda yaşamaktadır. Tüketebilmenin verdiği haz ve mutluluk, bazı ev kadınlarında öylesine ciddi biçimde yaşanmaktadır ki, elde ettikleri bu hislerini çılgınlık olarak tanımlamaktadırlar. Bu duruma örnek ise yine araştırma kapsamına giren ev kadınlarına sorulan soruya verdikleri yanıtlardan verilebilir: Z.Y. (33) "Çılgınlık 
geliyor aklıma. Alışveriş deyince aklıma çılgınlık geliyor.", Z.U. (33) "Alışveriş deyince akla çılgınlık gelir".

Tüketim toplumunda mutlu yaşam, tüketen ve tüketebilenin yaşamıdır. Sefalet ise tüketim toplumunun kabul ettiği mutlu ve normal yaşama katılımdan dışlanmadır (Yanıklar, 2006: 217). Bu şekilde dayatılan ve algılanan tüketim, elbette ki çılgınlık olarak tanımlanabilmekte ve mutlu olmanın, zevk duymanın sınırının kalktığı bir zamanda yaşanmaya çalışılan hazzın ileri boyutu olarak karşımıza çıkmaktadır. Bu şekilde psikolojik bir tatminin ve yaşam tarzına katılımın unsuru olarak sunulan tüketim, katılımcılardan N.Ö. (43) tarafından "Alışveriş bir hastalıktır. Bu hastalı̆̆a kapıldı̆̆ın zaman bırakamazsın." şeklinde ifade edilmiştir. Burada ev kadınının ifade ettiği hastalık fiziki anlamda bir arazı değil, psikolojik anlamda kendini doyumsuzluk olarak gösteren bir durumu anlatmak için kullanılmıştır. Tüketim çılgınlığı olarak adlandırılan ve sınırsız tüketme isteğini ifade eden algılayış, katılımcı tarafından hastalık olarak dillendirilmiştir.

Hastalık derecesinde bir arzu ve isteğin temeli olan tüketim, adeta yaşamın merkezine yerleşmiş ve yaşamın kendisinin tüketim odaklı olarak tanımlandığı hale dönüşmüştür. Tüketim toplumuna özgü temel referanslardan biri olan bu durum, yine araştırma kapsamına giren ev kadınlarından S.A. (63)'nın "Alışveriş hayatın bir vazgeçilmezidir. Alışveriş yapmadan ne hayat sürer ne de hayat yürür. Durur yani." biçimindeki yanıtından ortaya çıkmaktadır. Dikkat edilmesi gereken husus ise tüketimi yaşamın vazgeçilmez unsuru olarak sunan kişinin altmış yaşını geçmiş bir ev kadını olmasıdır. Tüketim toplumunda tüketimin adeta bir tutkuya dönüştüğünün, yaş değişkenine bağlı olmaksızın ev kadınları tarafindan kabul edilmesi oldukça dikkat çekici bir sonuçtur.

\section{Sonuç}

Tüketmeye ilişkin pratiklerin belirimi, tüketicilerin tüketim eğilim, alışkanlık, algı ve yaklaşımları temelinde gerçekleşmektedir. Tüketmeye ilişkin bu tür değerlendirmeler ise belli bir toplumsal yapı içerisinde sosyalleşerek oluşmaktadır. Endüstri öncesi toplum biçimlerinden başlayarak, her toplum tipinde yapıya yerleşmiş olan tüketim eğilim ve pratikleri, o toplum tipinin yapısal olarak oluşturduğu iktisadi ilişkileri ile doğrudan bağlantılıdır. Örneğin yaşamını sürdürmek için kendi ürettiği ürün ve deneyimleri tüketmek zorunda olan bir avc1-toplayıcı ya da tarım toplumu üyesi ile endüstrileşmiş bir toplumsal yapıda endüstriyel biçimde üretilmiş olan ürün ve deneyimleri tüketmek zorunda olan sanayi toplumu üyesi arasında tüketimi algılama bakımından ciddi farklılıklar söz konusudur.

Buradan hareketle, sanayi toplumunun geçirdiği değişim ve dönüşümler neticesinde gelinen sanayi sonrası aşamada tüketim ve tüketim pratiklerinin artan önemi ile birlikte, bu dönemin tüketicisi de daha önceki tüketici profillerinin dışında ve ciddi farklılıklar içeren eğilim ve yaklaşımlara sahiptir. Önceki dönemden farklı olarak öne çıan en önemli tüketim eğilimi, ihtiyaç temelli tüketme pratiklerinin yerini sembolik anlam temelli gerçekleşen tüketim pratiklerinin almış olmasıdır. Hem meta üretiminde teknolojik gelişmelerden kaynaklanan yenilikler hem de meta tüketimine ilişkin çeşitli araçlar dolayımıyla ortaya çıkan talep artışları, tüketime yönelik gerçekleşen sembolik değer temelli yeni eğilimlerin ortaya çıkışı ile ilişkilidir.

Teorik olarak tüketim toplumu aşamasında benzer tüketim eğilimlerinin ortaya çıktığı kabulüne dayanan bu çalışmada, bu aşamanın tüketici kesimlerinden biri olan ev kadınları arasında benzer tüketim eğilimlerinin ortaya çıkıp çıkmadığı belirlenmeye çalışılmıştır. Yapılan alan araştırması sonrasında, ev kadınlarının hem ihtiyaç temelli tüketim eğilimleri hem de sembolik anlam temelli tüketim eğilimleri geliştirdikleri tespit edilmiştir. Ancak tüketme pratik ve eğilimlerini belirlemek üzere geliştirilen metalaştırma araçlarının dolayımına açık olan ve tüketim toplumu yapısı içerisinde sosyalleşmiş olan genç ev kadınlarının tamamının sembolik anlam temelli tüketim eğilim ve pratikleri geliştirmiş olmaları, çalışmanın en önemli sonucu olarak dikkat çekmektedir. Tüketim toplumu öncesi dönemde sosyalleştiği düşünülen 50 yaş üzeri ev kadınlarının tamamının ihtiyaç temelli tüketim eğilim ve pratiklerine sahip olması ise tüketim toplumu aşamasına ilişkin geliştirilen teorilerle paralellik arz etmektedir. Araştırma verilerine göre tüketimi ihtiyaç temelli değerlendiren ev kadınları ihtiyacı, geleneksel anlamda yaşamı sürdürme bilinci ve anlayışı içerisinde algılamaktadırlar. Evin fiziksel düzenlenişi ve bireylerin fiziksel ihtiyaçlarına iliş̧in geliştirilen bu eğilim, tüketilen metanın faydası bağlamında ortaya çıkan metaların kullanım değeri ile bağlantılı bir yaklaşıma işaret etmektedir. Yine araştırma verilerine göre genç ev 
kadınlarının tamamı tüketimi ihtiyaç temelli değerlendirmelerine rağmen ihtiyaç kavramını farklı algılamaktadır. Genç ev kadınları için ihtiyaç, bireyin kendisi ve dış görünüşü bağlamında bedenine yaptığı harcamalarla ilişkilidir. Bireysel ve bedensel bu tür harcamalar ile ilişkili değerlendirilen ihtiyaç temelli tüketme eğilimi ise kişisel mutluluğun, hazzın ve isteğin kaynağı olarak değerlendirilmesi yönüyle metaların sembolik değerleri ile algılanmasına işaret eden bir yaklaşımdır.

Tüketmenin, tüketim toplumu aşamasında tüketici için haz almak, mutlu olmak, zevkli bir uğraş olma ve kişiyi iyi hissettirme şeklinde çeşitli duygulara kaynaklık ettiği şeklindeki genel kabule paralel olarak Arabanlı ev kadınlarının da tüketime ilişkin benzer bir eğilim geliştirdiği ortaya çıkmıştır. Metaların taşıdığı sembolik anlam bağlamında değerlendirilen tüketim, Arabanlı ev kadınları tarafından mutluluk, özgürlük, çılgınlık, rahatlık ve hastalık şeklinde tanımlanmaktadır. Bu bağlamda genç ev kadınlarının neredeyse tamamının, tüketme pratiğini geliştirirken tüketim ile ortaya çıkan haz ve mutluluğun arayışını tükettiği söylenebilir. Bu tür veriler ise, tüketilen metada gizli olan anlamların tüketici olarak ev kadınları tarafindan içselleştirildiğine işaret etmektedir. Bu bağlamda özellikle genç ev kadınları, tüketim toplumunun metalaştırma araçları dolaymıyla sosyalleşmeleri sebebiyle, kapalı bir toplum yapısı içerisinde yaşamalarına rağmen tüketim toplumunun tüketici tipini yansıtmaktadır. $\mathrm{Bu}$ yansıtışın en önemli gösterge verisi ise özellikle genç ev kadınlarının tüketme pratiklerini gerçekleştirirken erken ve ani biçimde alışverişten sıkılmaları ve usanmalarıdır. Bu yönüyle Arabanlı ev kadınlarının tüketim eğilimleri, tüketim toplumunda tüketimin geçici bir heves olarak değerlendirildiği biçimindeki teorik kabulle paralellik arz etmektedir.

Bilgilendirme/Acknowledgement: Doç. Dr. Beyzade Nadir Çetin danışmanlığında tamamlanmış olan yüksek lisans tezinden üretilmiştir.

\section{KAYNAKÇA}

Baudrillard, J. (2016). Simülakrlar ve simülasyon. (çev. O. Adanır). Ankara: Doğu Batı Yayınları.

Baudrillard, J. (2012). Tüketim toplumu söylenceleri/yapıları. (çev.H. Deliçaylı ve F. Keskin). İstanbul: Ayrintı Yayınları.

Bauman, Z. (1999). Çalışma, tüketicilik ve yeni yoksullar. (çev. Ü. Türkmen). İstanbul: Sarmal Yayınevi.

Bocock, R. (2009). Tüketim. (çev. İ. Kutluk). Ankara: Dost Kitabevi Yayınları.

Coser, L.A. (2008). Sosyolojik düşüncenin ustalarl/tarihsel ve toplumsal bağlamlarında fikirler. (çev. H. Hülür, S. Toker ve İ. Mazman). Ankara: DeKi Basım Yayın.

Çetin, B.N. (2017). Metalaştırma kapitalist sistemin tüketime ikna stratejisi. Ankara: Akçağ Yayınları.

Douglas, M. ve Isherwood, B. (1999). Tüketim antropolojisi. Ankara: Dost Kitabevi Yayınları.

Erkilet, A. (2012). Mahremiyetin dönüşümü: Değer, taklit ve gösterişçi tüketim bağlamında "İslami" moda dergileri. Birey ve Toplum, 2(4), 27-39.

Featherstone, M. (2013). Postmodernizm ve tüketim kültürü. (çev. M. Küçük). İstanbul: Ayrıntı Yayınları.

Fiske, J. (1999). Popüler kültürü anlamak. (çev. S. İrvan). Ankara: Bilim ve Sanat Yayınları/Ark.

Fromm, E. (2018). Sahip olmak ya da olmak. (çev. A. Arıtan). (Yedinci Baskı). İstanbul: Say Yayınevi.

Odabaş1, Y. (1999). Tüketim kültürü-yetinen toplumun tüketen topluma dönüşümü. İstanbul: Sistem Yayıncilik.

Robins, K. (1999). İmaj. (çev. N. Türkoğlu). İstanbul: Ayrıntı Yayınları.

Storey, J. (2000). Popüler kültür çalışmaları kuramlar ve metodlar. (çev. K. Karaşahin). İstanbul: Babil Yayınları.

Şaylan, G. (2009). Postmodernizm. Ankara: İmge Yayınevi. 
Üstün, B. ve Tutal, O. (2008). Tüketim alışkanlıklarındaki değişimler ve bu değişimlerin alışveriş mekânlarına etkisinin Eskişehir örneğinde irdelenmesi. Anadolu Üniversitesi Sosyal Bilimler Dergisi, 8(2), 259-282.

Veblen, T. (2005). Aylak sinıfin teorisi. (çev. Z. Gültekin ve C. Atalay). İstanbul: Babil Yayınları.

Wernick, A. (1996). Promosyon kültürü reklam, ideoloji ve sembolik anlatım. (çev. O. Akınhay). Ankara: Bilim ve Sanat Yayınları.

Yanıklar, C. (2006). Tüketim sosyolojisi. İstanbul: Birey Yayıncılık.

Zorlu, A. (2008). Alışveriş merkezlerini anlamak. Ankara: Global Yayınc1lık. 